\title{
Pelatihan Penggunaan Fish Finder Untuk Peningkatan Produksi Perikanan Kelompok Nelayan Tuna Dumai
}

\author{
Muhammad Nur Arkham ${ }^{1}$, Fajar Miftakhul Rizqy², Isa Elfianto², Diaz Anthera ${ }^{2}$, \\ Juniawan Preston Siahaan ${ }^{1}$, Iskandar Musa ${ }^{1}$, Roma Yuli F Hutapea ${ }^{1}$, Nirmala Efri \\ Hasibuan $^{1}$, Muhammad Ali Rozaki ${ }^{1}$, Rizqi Ilmal Yaqin ${ }^{1}$ \\ ${ }^{1}$ Marine and Fisheries Polytechnic of Dumai, Kota Dumai, Indonesia \\ ${ }^{2}$ Community Development Officer PT Pertamina RU II Dumai, Kota Dumai, Indonesia \\ arkham.mnur@gmail.com
}

\begin{abstract}
Abstrak
Penerapan ilmu dan teknologi dalam aktivitas perikanan tangkap berbasis sumber daya akan mampu memenuhi kebutuhan nelayan secara berkelanjutan. Salah satu teknologi penangkapan yang dapat membantu nelayan dalam aktivitas penangkapan ikan adalah fish finder. Tujuan dari kegiatan pengabdian ini adalah untuk memberikan edukasi dan meningkatkan keterampilan kelompok nelayan melalui penggunaan fish finder dalam membantu mendeteksi keberadaan ikan yang nantinya mampu meningkatkan penangkapan ikan hasil tangkapan. Kegiatan pengabdian kepada masyarakat ini menggunakan metode pendekatan pengembangan masyarakat melalui pelatihan berdasarkan teori dan praktik serta diskusi kelompok secara terarah (FGD). Kegiatan pelatihan penggunaan fish finder berlangsung dengan baik, semangat dan partisipasi dari para peserta. Pelaksanaan pelatihan ini dilaksanakan dengan 2 konsep pendekatan yaitu kelas teori dan kelas praktik. Materi yang diberikan dalam kelas teori meliputi pengetahuan dan perkembangan penggunaan fish finder secara global, sedangkan untuk kelas praktik dilaksanakan pengoperasian fish finder langsung di atas kapal. Hasil dari monitoring dan evaluasi menyebutkan bahwa nelayan mendapatkan banyak manfaat dalam menggunakan alat bantu penangkapan fish finder dalam membantu mendeteksi keberadaan ikan sehingga mampu mengurangi biaya operasional, meningkatkan hasil tangkapan dan menemukan daerah tangkapan (fishing ground) lebih mudah.
\end{abstract}

Kata Kunci: Fish Finder, Perikanan Skala Kecil, Kelompok Nelayan Tuna, Dumai

\begin{abstract}
The application of science and technology in resource-based capture fisheries activities will be able to meet the needs of fishermen in a sustainable manner. One fishing technology that can help fishermen in fishing activities is a fish finder. The purpose of this community service activity is to provide education and improve the skills of fishing groups through the use of fish finders to help detect the presence of fish that will later be able to increase the catch of catching fish. This community service activity uses a community development approach method through training based on theory and practice as well as focus group discussions (FGD). Training activities on the use of fish finder took place well, enthusiastic and participatory from the participants. The training was carried out with 2 concept approaches namely the theory class and the practice class. The material provided in the theory class covers the knowledge and development of the use of fish finders globally, while for the practical classes the operation of fish finders is carried out directly on board. The results of monitoring and evaluation stated that fishermen get many benefits in using a fishing finder to help detect the presence of fish so that they can reduce operational costs, increase catches and find fishing ground more easily.
\end{abstract}

Keywords: Fish Finder, Small-Scale Fisheries, Tuna Fisherman Group, Dumai 


\section{PENDAHULUAN}

Perikanan tangkap merupakan aktivitas ekonomi dari masyarakat dalam bidang perikanan atau pengumpulan hewan atau tanaman air yang hidup di laut atau perairan umum secara bebas. Aktivitas perikanan tangkap ini bertujuan untuk mendapatkan keuntungan baik secara finansial maupun untuk memperoleh nilai tambah lainnya seperti penyerapan tenaga kerja, pemenuhan kebutuhan terhadap protein hewani, devisa serta pendapatan negaral. Pemanfaatan sumber daya perikanan tersebut tidak akan maksimal, jika tidak didukung oleh pengetahuan dan teknologi penangkapan yang berkelanjutan. Teknologi penangkapan yang unggul dan berbasis sumber daya diharapkan mampu menunjang aktivitas perikanan, sehingga dapat memenuhi kebutuhan manusia, menjaga keberlanjutan sumber daya dan mampu meningkatkan keterampilan manusia dalam penerapan teknologi.

Penerapan teknologi modern pada sarana dan teknik-teknik yang di pakai, termasuk alat penangkapan ikan, perahu atau kapal dan alat bantu lainnya yang di sesuaikan dengan kondisi masing-masing tempat. Namun tidak semua modernisasi dapat menghasilkan peningkatan produksi dan peningkatan pendapatan bersih (net income) nelayan. Oleh karena itu introduksi teknik-teknik penangkapan ikan yang baru harus di dahului dengan penelitian dan percobaan yang intensif dengan hasil yang meyakinkan ${ }^{2}$. Upaya pengelolaan dan pengembangan sumber daya perikanan di masa mendatang akan menjadi lebih berat dan kompleks seiring dengan perkembangan ilmu pengetahuan dan teknologi (IPTEK). Akan tetapi, dengan pemanfaatan IPTEK tersebut diharapkan dapat mengatasi keterbatasan sumber daya melalui suatu langkah yang rasional untuk mendapatkan manfaat yang optimal dan berkelanjutan. Langkah pengelolaan dan pengembangan tersebut juga harus mempertimbangkan aspek biologi, teknis, sosial, budaya dan ekonomi ${ }^{3}$.

Kota Dumai merupakan salah satu kota yang terletak di pesisir timur Provinsi Riau. Sebagian besar masyarakat Pesisir Kota Dumai bermata pencaharian sebagai nelayan kecil/ tradisional. Penyebaran nelayan yang ada di Kota Dumai sebagian besar berada di empat kecamatan yaitu Dumai Barat, Dumai Timur, Medang Kampai dan Sungai Sembilan. Jumlah nelayan yang ada di Kota Dumai sampai dengan tahun 2018 tercatat 245 Rumah Tangga Perikanan (RTP) atau setara 735 jiwa $^{4}$. Sebagian besar nelayan yang ada di Kota Dumai kemampuan dan pemahaman terhadap teknologi penangkapan ikannya masih tergolong rendah, hal ini ditandai dengan aktivitas penangkapan yang mereka lakukan yaitu pencarian ikan secara acak dan berdasarkan

1 Monintja, D.R. "Pengembangan Perikanan Tangkap Berwawasan Lingkungan". (Seminar Pengembangan Agribisnis Perikanan pada Sekolah Tinggi Perikanan Jakarta. Agustus 1994. Jakarta.).

2 Wisudo, S.H., Nurani, T.W., \& Zulkarnain. Teknologi Penangkapan ikan yang layak Dikembangkan di Labuan, Jawa Barat. (IPB University: FPIK-IPB University, 1994).

3 Barus, H., Badrudin, \& Naamin, N. "Potensi Sumberdaya Perikanan Laut dan Strategi Pemanfaatannya Bagi Pengembangan Perikanan yang Berkelanjutan". (Prosiding Forum II Perikanan, Sukabumi, 18-21 Juni 199l. Pusat Penelitian dan Pengembangan Pertanian Departemen Pertanian Republik Indonesia, Jakarta.).

4 Badan Pusat Statistik. Kota Dumai Dalam Angka 2019. (BPS Kota Dumai: Dumai). 
informasi dari nelayan lain terkait dengan lokasi penangkapan (fishing ground). Hal tersebut membuat aktivitas perikanan tangkap yang ada di Kota Dumai masih belum efektif dan efisien.

Kemampuan nelayan dalam menerapkan teknologi penangkapan ikan di Kota Dumai masih perlu ditingkatkan sering dengan perkembangan ilmu pengetahuan dan teknologi (IPTEK). Salah satu teknologi alat bantu penangkapan yang sering digunakan oleh nelayan secara umum dalam mendeteksi keberadaan ikan adalah fish finder. Berdasarkan hasil penelitian ${ }^{5}$ menunjukkan bahwa hasil tangkapan ikan dengan aplikasi fish finder jauh lebih besar dan lebih hemat bahan bakar. Kelebihan penggunaan teknologi alat bantu perikanan tersebut masih belum diketahui dan diterapkan oleh nelayan di Kota Dumai, sehingga dengan kondisi tersebut tim Pengabdian Kepada Masyarakat Politeknik KP Dumai bekerja sama dengan CSR Pertamina RU II Dumai melakukan sosialisasi dan pelatihan penggunaan Fish Finder untuk meningkatkan produksi penangkapan ikan khususnya nelayan di Kota Dumai. Kegiatan pengabdian ini bertujuan untuk memberikan edukasi dan peningkatan keterampilan kepada nelayan khususnya kelompok nelayan Tuna tentang manfaat penggunaan fish finder dalam membantu mendeteksi keberadaan ikan, sehingga nantinya diharapkan mampu meningkatkan produksi perikanan tangkapan.

\section{METODE PELAKSANAAN}

\section{A. Waktu dan Tempat Pelaksanaan}

Kegiatan Pengabdian Kepada Masyarakat tentang Pelatihan Penggunaan Fish Finder ini dilaksanakan 2 hari sesuai dengan kelasnya: (a) Kelas Teori dimulai pada Hari Kamis, 13 Februari 2020, waktu dari 09.00 WIB - Selesai, yang bertempat di Kantor Kelurahan Tanjung Palas, Kecamatan Dumai Timur. (b) Kelas Praktik dimulai Hari Minggu, 16 Februari 2020, waktu dari 10.00 WIB - Selesai, yang bertempat di Pangkalan Pendaratan Kapal Kelurahan Tanjung Palas, Kecamatan Dumai Timur.

\section{B. Kerangka Pendekatan Masalah}

Kelompok Nelayan Tuna, Kelurahan Tanjung Palas merupakan kelompok yang aktif dalam melakukan kegiatan penangkapan ikan skala kecil/tradisional. Ketrampilan, ilmu pengetahuan dan teknologi terkait dengan penangkapan Kelompok Nelayan Tuna masih rendah, sehingga mereka masih melakukan penangkapan dengan menentukan daerah tangkapan secara acak dan hanya berdasarkan informasi dari nelayan lainnya. Solusi alternatif untuk permasalahan pengetahuan nelayan tentang teknologi penangkapan nelayan akan menjadi fokus utama penulis. Salah satu solusi alternatif yang dapat dilakukan adalah dengan kegiatan pelatihan penggunaan fish finder sebagai alat bantu

5 Bhagya, T.G., \& Prakarsa, G. "Studi Kelayakan Penerapan Teknologi GPS dan Fish Finder untuk Meningkatkan Hasil Tangkapan Ikan”. (2016) In Search, (15) 2: 55-60. 
penangkapan untuk meningkatkan produksi perikanan nelayan. Kegiatan ini juga berpotensi untuk meningkatkan kesadaran masyarakat akan arti penting mengikuti perkembangan ilmu pengetahuan dan teknologi perikanan secara efektif, efisien dan berkelanjutan.

\section{Langkah Pelaksanaan}

Kegiatan pengabdian kepada masyarakat ini menggunakan metode pendekatan community development atau pengembangan masyarakat. Strategi pengembangan ini diberikan kepada kelompok Nelayan Tuna sesuai dengan kearifan yang dimiliki. Langkah-langkah yag dilakukan dalam strategi pengembangan masyarakat dalam menyelesaikan persoalan tersebut adalah melalui pelatihan berdasarkan teori dan praktik melalui ceramah dan diskusi kelompok secara terarah $(\mathrm{FGD}=$ Focus Group Discussion). Pemateri kegiatan ini adalah Dosen dari Program Studi Perikanan Tangkap di Politeknik Kelautan dan Perikanan Dumai. Peserta berasal dari kelompok nelayan Tuna, Kelurahan Tanjung Palas.

Proses pelatihan menggunakan alat audio visual, proyektor/infokus, dan spidol. Setiap peserta mendapatkan materi dalam bentuk makalah dan alat tulis. Materi yang ditampikan saat proses diskusi adalah power point dan pengenalan terhadap fish finder dengan setiap kelompok peserta mengamati unit alat tersebut. Selain itu juga dilakukan praktik praktik penggunaan fish finder di atas kapal. Kelompok nelayan nantinya diharapkan dapat mengoperasikan sendiri alat bantu penangkapan fish finder.

Langkah-langkah kegiatan yang akan dilaksanakan adalah:

1. Survey dan wawancara. Pada tahapan ini, tim pengabdian akan melakukan survey dan wawancara kepada kelompok nelayan mengenai pengetahuannya terhadap fish finder dan pengoperasiannya. Kemudian tim pengabdian juga melakukan studi literatur tentang peningkatan pengetahuan penggunaan fish finder.

2. Persiapan alat Bahan dan waktu kegiatan. Tahapan ini berupa persiapan alat dan bahan yang akan digunakan.

3. Waktu pelaksanaan. Pelaksanaan pelatihan dilakukan selama dua hari, dimana satu hari dilaksanakan kelas teori dan kelas praktik pengoperasiaannya di atas kapal juga dilakukan selama satu hari.

4. Evaluasi. Tahapan evaluasi akan dilakukan pada saat setelah pelatihan.

\section{HASIL DAN PEMBAHASAN}

Pembangunan perikanan sangat erat kaitannya dengan proses pemanfaatan sumber daya alam, sumber daya manusia dan sumber daya dana yang tersedia. Berdasarkan sifat sumber daya alamnya, pengembangan usaha perikanan tangkap sangat tergantung pada ketersediaan sumber daya perikanan di suatu perairan. Fluktuasi kegiatan usaha perikanan pada akhirnya mempengaruhi nelayan yang beroperasi di sekitar tersebut. Berdasarkan sifat sumber daya manusianya, ilmu pengetahuan dan teknologi (IPTEK) menjadi sangat penting untuk pemanfaatan sumber daya perikanan secara 
berkelanjutan. Faktor manusia menjadi kunci kesuksesan dalam pengelolaan perikanan secara berkelanjutan, hal ini dikarenakan manusia melakukan pemanfaatan sumber daya perikanan dengan memiliki emosi, strategi, visi, tujuan, keinginan, dan perasaan. Pentingnya dalam mengelola sumber daya perikanan dikarenakan beberapa hal, di antaranya beberapa pihak yang terlibat dalam pengelolaan perikanan seperti peran pemerintah, nelayan, dan stakeholder lain yang terkait, dengan manfaat agar sektor perikanan dapat memberikan manfaat secara optimal bagi para stakeholder baik untuk generasi sekarang, maupun yang akan datang serta terciptanya pemanfaatan perikanan yang bertanggung jawab ${ }^{6}$.

Sebagai salah satu instansi akademik yang bergerak dibidang Perikanan dan Kelautan, maka Politeknik Kelautan dan Perikanan Dumai melakukan kerja sama dengan CSR Pertamina RU II Dumai untuk melakukan salah satu kegiatan Pengabdian Kepada Masyarakat Politeknik KP Dumai dengan memberikan edukasi dan pelatihan terhadap nelayan tentang manfaat dan pentingnya menggunakan teknologi alat bantu penangkapan fish finder. Kegiatan ini diharapkan dapat mendorong dan meningkatkan kesadaran masyarakat akan pentingnya perkembangan ilmu pengetahuan dan teknologi dalam melaksanakan aktivitas perikanan tangkap, sehingga nantinya mampu meningkatkan hasil tangkapan dan pendapatan nelayan.

Kegiatan pengabdian ini berawal dari permasalahan yang terjadi terhadap nelayan di Kota Dumai secara umum bahwa nelayan yang akan melakukan penangkapan ikan menuju ke daerah tangkapan (fishing ground) masih secara acak dan terbatas pada informasi nelayan lain. Hal ini menyebab kegiatan penangkapan yang dilakukan oleh nelayan di Kota Dumai menjadi kurang efektif dan efisien, sehingga mereka harus melakukan penangkapan ikan yang lebih jauh dari pantai. Selain itu juga faktor kondisi lingkungan perairan pantai yang ada di Kota Dumai ini terganggu dengan beberapa aktivitas antropogenik seperti kegiatan pelayaran kapal-kapal, aktivitas industri, pelabuhan, dan kegiatan lainnya yang dapat memberikan dampak negatif terhadap kualitas perairan pantai Kota Dumai, sehingga dapat berdampak pada hasil tangkapan nelayan. Hasil penelitian ${ }^{7}$ juga menyebutkan bahwa aktivitas antropogenik di Kota Dumai sangat mempengaruhi kondisi lingkungan perairan Kota Dumai. Hal ini ditandai dengan berkurangnya jumlah hasil tangkapan nelayan, berkurangnya jumlah mangrove, dan seringnya terjadi rob/banjir di kawasan sekitar pesisir Kota Dumai beserta pulaupulau yang ada di sekitar Kota Dumai.

Pelaksanaan program pengabdian kepada masyarakat dilaksanakan selama 2 hari dengan waktu pelaksanaan yang berbeda. Kegiatan pelatihan ini dibagi menjadi 2 kelas, yaitu kelas teori dan kelas praktik. Kelas teori yaitu berisi tentang pemaparan dari narasumber (Dosen Politeknik KP Dumai program studi Perikanan Tangkap) tentang manfaat dan pengetahuan tentang fish finder yang dilanjutkan dengan kegiatan tanya

FAO. Fisheries Management. FAO Technical Guidelines for Responsible Fisheries. No. 4 Rome. 45 p (FAO, 1997).

7 Ariani, F. Strategi Pengelolaan Pencemaran Di Pesisir Perairan Kota Dumai. (IPB University: Tesis FPIK IPB University, 2016). 
jawab. Kelas praktik yaitu berisi tentang pemasangan fish finder pada kapal dan pelaksanaan penggunaan fish finder di atas kapal oleh nelayan untuk mendeteksi keberadaan ikan. Beberapa peserta yang diundang dalam pembukaan pelatihan ini di antaranya adalah pihak Kecamatan Dumai Timur, Kelurahan Tanjung Palas, Tokoh Adat, UM Comm, Rel, CSR RU II, Politeknik KP Dumai, Dinas Perikanan Kota Dumai, LSM Kota Dumai, dan Kelompok Nelayan Tuna. Berikut ini adalah uraian tahapan kegiatan pengabdian kepada masyarakat ini:

\section{A. Persiapan}

Sebelum dilaksanakan kegiatan pelatihan pengenalan dan penggunaan fish finder sebagai teknologi alat bantu penangkapan, tim pengabdian melakukan beberapa persiapan. Persiapan tersebut mulai dari pelaksanaan pelatihan, persiapan alat dan bahan, serta persiapan logistik (sarana dan prasarana) yang akan digunakan selama pelatihan. Tim pengabdian dalam kegiatan ini terdiri dari Tim Politeknik KP Dumai (PKPD) dan Tim dari CSR Pertamina RU II Dumai. Berikut ini adalah beberapa list persiapan dari tim pengabdian dapat dilihat pada Tabel 1.

Tabel 1 Aktivitas persiapan pelatihan penggunaan fish finder

\begin{tabular}{|c|c|c|}
\hline No & Aktivitas & Penanggung Jawab \\
\hline 1 & $\begin{array}{l}\text { Persiapan alat dan bahan tambahan dalam } \\
\text { pengoperasian fish finder }\end{array}$ & $\begin{array}{ll}\text { Tim } & \text { Pengabdian } \\
\text { PKPD } & \end{array}$ \\
\hline 2 & Persiapan pembelian alat bantu penangkapan fish finder & Tim CSR RU II \\
\hline 3 & $\begin{array}{l}\text { Persiapan penyesuaian waktu pelaksanaan dengan } \\
\text { kegiatan nelayan }\end{array}$ & Tim CSR RU II \\
\hline 4 & $\begin{array}{l}\text { Persiapan lokasi/tempat untuk kelas teori dan kelas } \\
\text { praktik }\end{array}$ & Tim CSR RU II \\
\hline 5 & $\begin{array}{l}\text { Persiapan sarana dan prasarana (seperti kapal nelayan, } \\
\text { logistik, infokus dan lainnya) }\end{array}$ & Tim CSR RU II \\
\hline 6 & Persiapan bahan paparan/presentasi untuk kelas teori & Pengabdian \\
\hline
\end{tabular}

Persiapan yang dilakukan tim utamanya adalah memilih tipe fish finder yang akan digunakan oleh kelompok Nelayan Tuna. Penentuan jenis dan tipe fish finder yang akan diberikan/diinventariskan kepada kelompok nelayan, antara Tim PKPD dan Tim CSR RU II selalu melalui tahap diskusi dan studi literatur. Hasil dari pencarian studi literatur dan diskusi dengan tim dan para pakar, maka untuk pelaksanaan pelatihan ini akan menggunakan fish finder dengan tipe Garmin FF-350 (Gambar 1). Alat ini mempunyai banyak keunggulan dan para nelayan akan lebih mudah dalam mengoperasikannya. Beberapa keunggulan dari tipe FF-350 di antaranya adalah":

8 https://www.garmin.co.id/products/onthewater/ff-350-plus/ 
1. Dukungan multibahasa: bahasa Inggris, bahasa Cina Sederhana, bahasa Jepang, bahasa Korea, bahasa Indonesia, bahasa Malaysia, bahasa Vietnam, bahasa Birma, bahasa Thailand.

2. Tersedia dalam ukuran layar WVGA 6 inci yang lebih besar dan jernih, berwarna dan dalam mode potret. Menawarkan antarmuka bertombol dengan tomboltombol khusus.

3. Output daya sonar $300 \mathrm{~W}$ (RMS) dan teknologi pelacakan target Garmin HDID $^{\mathrm{TM}}$ ekstra sensitif bawaan. Fleksibilitas untuk mendukung 50/77/200 kHz untuk penggunaan di air dangkal atau air dalam.

4. Dilengkapi dengan sonar pemindaian ClearVü bawaan. Sonar frekuensi tinggi ini menghasilkan gambar yang lebih jelas dari apa yang ada di bawah kapal dengan menghasilkan citra yang menyerupai foto dengan menampilkan objek, struktur, dan ikan dengan jelas.

5. Mode tampilan warna malam adalah pembacaan mudah selama kondisi cahaya redup untuk meningkatkan keselamatan saat bernavigasi.

6. Penampilan yang kokoh dan untuk penggunaan luar ruangan yang melengkapi gaya hidup Anda. Konektor baru dan knop untuk desain pemasangan gantung. Mampu bertahan dalam lingkungan laut yang keras dengan performa cemerlang.

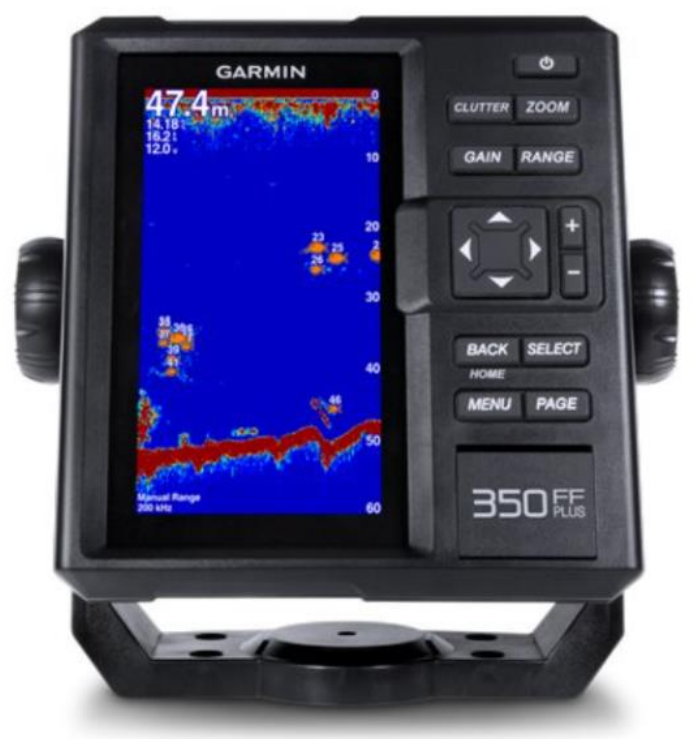

(Sumber: https://www.garmin.co.id/products/onthewater/ff-350-plus/)

Gambar 1 Fish finder tipe garmin FF-350

\section{B. Pelaksanaan Pelatihan}

1. Kelas teori 
Pelaksanaan kegiatan kelas teori pelatihan penggunaan fish finder pada Hari Kamis, 13 Februari 2020 tepat pukul 09.00 WIB yang bertempat di Balai Pertemuan, Kantor Kelurahan Tanjung Palas, Kecamatan Dumai Timur, Kota Dumai dimulai dengan pembukaan dan sambutan oleh beberapa undangan seperti perwakilan dari Kecamatan Dumai Timur, Sambutan UM Comm, Rel, CSR RU II, Sambutan Direktur Politeknik KP Dumai, dan Sambutan Kepala Dinas Perikanan Kota Dumai. Dalam sambutan tersebut dari pihak penyelenggara baik dari CSR Pertamina RU II Dumai dan Politeknik KP Dumai berharap dengan diadakan pelatihan ini maka akan memberikan tambahan pengetahuan dan keterampilan nelayan dalam melakukan penangkapan ikan, selain itu juga dapat memberikan dampak positif terhadap hasil tangkapan dan pendapatan dari Kelompok Nelayan Tuna.

Sambutan lainnya dari Kepala Dinas Perikanan Kota Dumai telah menyebutkan bahwa kegiatan pelatihan penggunaan alat bantu penangkapan fish finder ini merupakan kegiatan pelatihan pertama yang diadakan di Kota Dumai. Harapan dari Kepala Dinas Perikanan Kota Dumai menyebutkan bahwa dengan pelatihan ini maka dapat membantu nelayan untuk menemukan ikan lebih mudah dan lebih efisien, sehingga nantinya bisa menjadi salah satu role model (percontohan) bagi nelayan lain yang ada di Kota Dumai akan pentingnya teknologi dalam mendorong kegiatan perikanan tangkap yang berkelanjutan (sustainable).

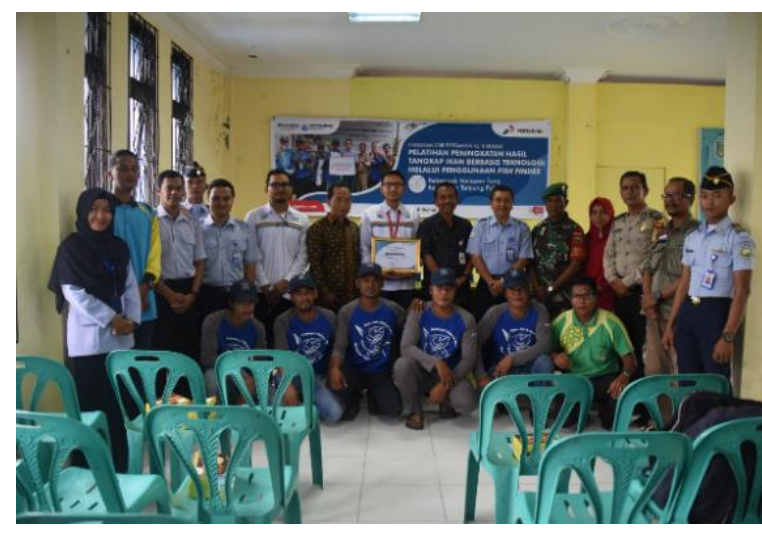

(a)

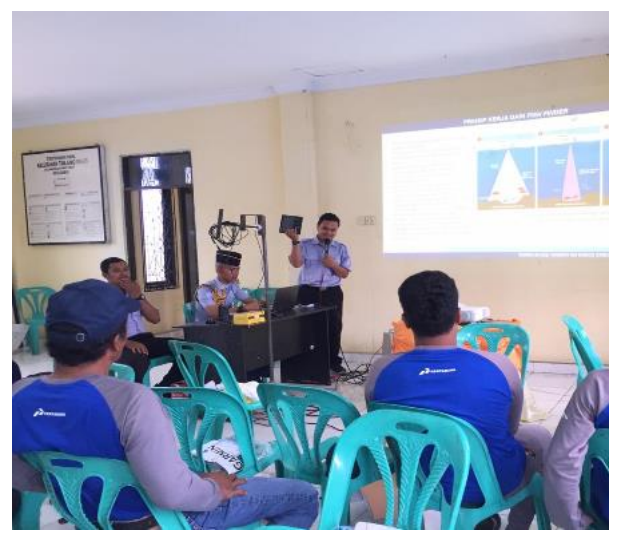

(b)

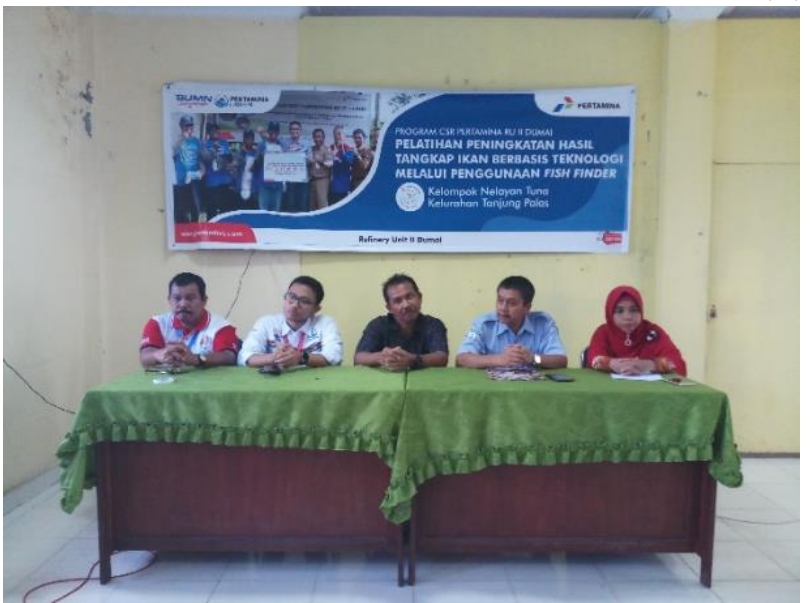

(c) 
Gambar 2. Kegiatan pelatihan dengan skema kelas teori: (a) foto bersama; (b) pemberian materi oleh narasumber; (c) sambutan pembukaan kegiatan

Acara selanjutnya dilakukan foto bersama antara peserta dengan para tamu undangan pelatihan, setelah itu dilanjutkan dengan pemaparan oleh narasumber Dosen Politeknik KP Dumai oleh bapak Muhammad Nur Arkham, S.Pi, M.Si. Pemberian materi dari narasumber ini bersifat transfer pengetahuan (sharing knowledge) kepada kelompok nelayan tentang pentingnya penggunaan alat bantu penangkapan fish finder dalam aktivitas penangkapan. Pemaparan materi berbentuk ceramah dengan power point dan penayangan video kepada peserta pelatihan (Gambar 2). Transfer pengetahuan ini sangat diperlukan untuk memberikan motivasi nelayan tentang keuntungan yang didapat oleh nelayan apabila menggunakan fish finder. Beberapa materi yang dipaparkan oleh narasumber kepada peserta pelatihan di antaranya dapat dilihat pada Tabel 2.

Tabel 2 Materi yang diberikan saat Kelas Teori

\begin{tabular}{|l|l|}
\hline No & Materi \\
\hline 1 & Pengertian dari fish finder dan pengenalan terhadap beberapa tipe fish finder \\
\hline 2 & Sejarah dan perkembangan penggunaan fish finder dalam dunia perikanan \\
\hline 3 & Kelebihan dan kekurangan dalam penggunaan fish finder \\
\hline 4 & Bagian-bagian dari fish finder \\
\hline 5 & Prinsip kerja dari fish finder \\
\hline 6 & Pengenalan dan pengoperasian unit fish finder tipe Garmin FF-350 \\
\hline
\end{tabular}

\section{Kelas praktik}

Pelaksanaan kegiatan kelas praktik pelatihan penggunaan fish finder yaitu pada Hari Minggu, 16 Februari 2020 tepat pukul 10.00 WIB yang bertempat di Pendaratan Kapal Jalan Bandes, Kelurahan Tanjung Palas, Kecamatan Dumai Timur, Kota Dumai dan diteruskan dengan pengoperasiannya di perairan sekitar Kota Dumai dengan menggunakan 2 kapal. Kegiatan yang dilakukan pada kelas praktik dalam pelatihan ini adalah tentang perakitan fish finder dan alat tambahannya serta cara pengoperasian alat sesuai dengan Standar Operasional Prosedur (SOP) yang dikeluarkan oleh perusahaan pembuat fish finder. Selain itu juga diberikan pengetahuan terkait cara membaca informasi yang muncul di layar monitor fish finder.

Sebelum mengoperasikan fish finder di atas kapal, narasumber memberikan penjelasan dan pengarahan untuk kelancaran kegiatan pelatihan. Dalam pelaksanaannya kelas praktik ini dibagi menjadi 2 kelompok dengan setiap kelompoknya didampingi oleh narasumber dari Politeknik KP Dumai dan dibantu oleh Taruna Politeknik KP Dumai. Pelaksanaan praktik dimulai dengan perakitan dan pemasangan fish finder dan alat tambahan di atas kapal, kemudian narasumber menjelaskan kepada para peserta tentang pengoperasian fish finder tersebut. Penjelasan dari narasumber dalam kegiatan praktik tersebut yaitu dimulai dari mengaktifkan fish finder sampai dengan pengenalan 
beberapa tombol penting yang digunakan saat nelayan sedang mendeteksi keberadaan ikan. Setelah narasumber memberikan transfer pengetahuannya, nelayan diberikan kesempatan untuk mengoperasikan fish finder dan membaca hasil tangkapan gelombang yang dipantulkan pada dasar laut selanjutnya ditampilkan pada monitor. Peserta pelatihan sangat antusias dan bersemangat dalam melaksanakan kelas praktik. Peserta juga merasakan kemudahan dalam kegiatan penangkapan ikan menggunakan fish finder tersebut, selain itu juga peserta menjadi mengetahui kedalaman perairan secara akurat dalam melakukan penangkapan ikan.

Pelaksanaan kelas praktik pengoperasian fishfinder ini dilaksanakan sampai dengan pukul 12.00 WIB dengan melakukan pengoperasian langsung di atas kapal dan didampingi oleh narasumber pada setiap kapal. Selama kegiatan praktik berlangsung, para peserta dengan mudah memahami segala bentuk informasi dan beberapa aplikasi yang ada di dalam fish finder tipe Gramin FF-350. Beberapa peserta juga menjadi mengetahui keberadaan ikan yang ada di sekitar kapal dan juga ukuran ikan. Ukuran ikan yang dapat dideteksi oleh alat fish finder Garmin FF-350 ini terdapat 3 pilihan, yaitu besar, sedang dan kecil. Peserta juga merasa terbantu dengan informasi tentang kondisi substrat dasar yang ada di sekitar daerah tangkapan (fishing ground) yang diberikan oleh fish finder, sehingga nelayan lebih bisa berhati-hati dalam meletakkan alat tangkap dalam mengurangi kerusakan alat tangkap yang diakibatkan dari keberadaan benda asing atau batu karang yang ada di dasar perairan. Kegiatan pelatihan ini diakhiri dengan dilaksanakannya foto bersama antara peserta, narasumber dan fasilitator dari CSR Pertamina RU II Dumai di atas kapal (Gambar 3).
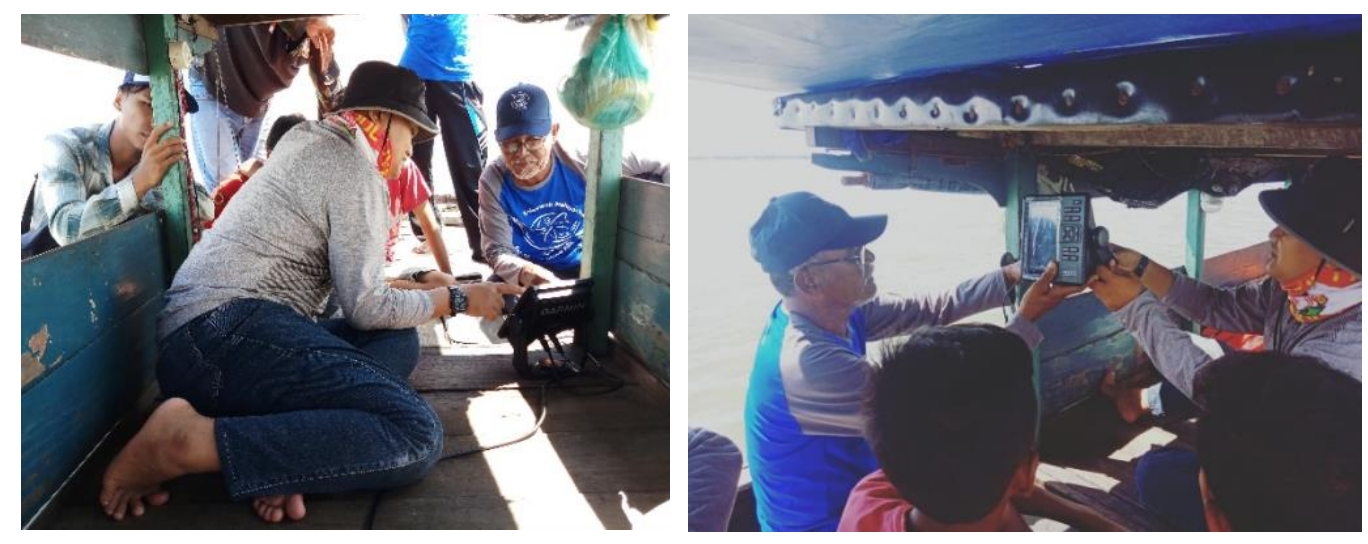


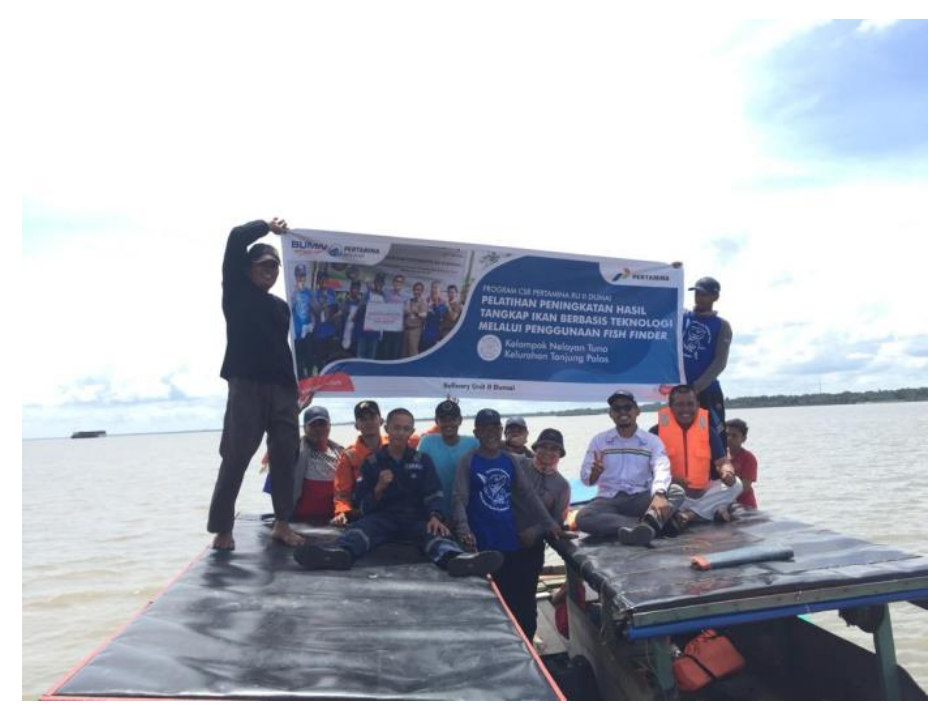

Gambar 3. Pelaksanaan pelatihan fish finder pada saat kelas praktik di atas kapal

\section{A. Monitoring dan Evaluasi}

Kegiatan pelatihan penggunaan fish finder untuk meningkatkan hasil tangkapan nelayan ini juga dilakukan monitoring dan evaluasi terhadap hasil pelatihan. Kegiatan monitoring dan evaluasi ini dibantu oleh pihak CSR Pertamina RU II Dumai. Berdasarkan hasil monitoring pelatihan menunjukkan bahwa Kelompok Nelayan Tuna dengan rutin menggunakan alat bantu penangkapan fish finder ini dalam melakukan penangkapan ikan. Nelayan merasakan lebih mudah dalam mendeteksi keberadaan ikan dan menentukan daerah penangkapan (fishing ground). Selain itu juga nelayan merasakan adanya pengurangan biaya operasional dalam melakukan penangkapan dengan menggunakan alat bantu fish finder tersebut, sehingga dirasa lebih efektif dan efisien. Nelayan juga merasakan mendapatkan hasil tangkapan lebih banyak dibanding biasanya. Untuk evaluasi dari pelatihan ini sendiri yaitu nelayan yang efektif dalam menggunakan alat bantu penangkapan fish finder ini adalah nelayan dengan alat tangkap jaring dalam mendeteksi keberadaan ikan, sedangkan untuk nelayan rawai dasar masih belum merasakan keuntungan dalam penggunaan fish finder tersebut. Hal ini dikarenakan ikan target tangkapan nelayan rawai dasar adalah jenis-jenis ikan dasar yang tidak dapat dideteksi secara detail (jenis ikannya) oleh fish finder.

Seluruh bagian ini mengikuti penjelasan sebelumnya.

\section{KESIMPULAN}

Kegiatan Pengabdian Kepada Masyarakat tentang Pelatihan Penggunaan Fish Finder Untuk Meningkatkan Produksi Perikanan dapat disimpulkan bahwa kegiatan berlangsung dengan baik, semangat dan partisipasi dari para peserta. Pelaksanaan pelatihan ini dilaksanakan dengan 2 konsep pendekatan yaitu kelas teori dan kelas praktik. Materi yang diberikan dalam kelas teori meliputi pengetahuan dan 
perkembangan penggunaan fish finder secara global, sedangkan untuk kelas praktik dilaksanakan pengoperasian fish finder langsung di atas kapal. Hasil dari monitoring dan evaluasi menyebutkan bahwa nelayan mendapatkan banyak manfaat dalam menggunakan alat bantu penangkapan fish finder dalam membantu mendeteksi keberadaan ikan sehingga mampu mengurangi biaya operasional, meningkatkan hasil tangkapan dan menemukan daerah tangkapan (fishing ground) lebih mudah.

\section{DAFTAR PUSTAKA}

Ariani, F. Strategi Pengelolaan Pencemaran Di Pesisir Perairan Kota Dumai. (IPB University: Tesis FPIK IPB University, 2016).

Badan Pusat Statistik. Kecamatan Dumai Timur Dalam Angka 2019. (Dumai: BPS Kota Dumai, 2019)

Badan Pusat Statistik. Kota Dumai Dalam Angka 2019. (BPS Kota Dumai: Dumai)

Barus, H., Badrudin, \& Naamin, N. "Potensi Sumberdaya Perikanan Laut dan Strategi Pemanfaatannya Bagi Pengembangan Perikanan yang Berkelanjutan”. (Prosiding Forum II Perikanan, Sukabumi, 18-21 Juni 1991. Pusat Penelitian dan Pengembangan Pertanian Departemen Pertanian Republik Indonesia, Jakarta.)

Bhagya, T.G., \& Prakarsa, G. "Studi Kelayakan Penerapan Teknologi GPS dan Fish Finder untuk Meningkatkan Hasil Tangkapan Ikan”. (2016) In Search, (15) 2: 55-60.

FAO. Fisheries Management. FAO Technical Guidelines for Responsible Fisheries. No. 4 Rome. 45 p (FAO, 1997)

https:/www.garmin.co.id/products/onthewater/ff-350-plus/

Monintja, D.R. "Pengembangan Perikanan Tangkap Berwawasan Lingkungan”. (Seminar Pengembangan Agribisnis Perikanan pada Sekolah Tinggi Perikanan Jakarta. Agustus 1994. Jakarta.)

Wisudo, S.H., Nurani, T.W., \& Zulkarnain. Teknologi Penangkapan ikan yang layak Dikembangkan di Labuan, Jawa Barat. (IPB University: FPIK-IPB University, 1994). 